\title{
Coil and shape in Partula suturalis: the rules of form revisited
}

\author{
A Davison $^{1}, \mathrm{~N}$ Constant $^{1}, \mathrm{H} \mathrm{Tanna}^{1}{ }^{1}, \mathrm{~J} \mathrm{Murray}^{2}$ and B Clarke ${ }^{1}$ \\ ${ }^{1}$ Institute of Genetics, School of Biology, Queen's Medical Centre, University of Nottingham, Nottingham, UK and 'Department \\ of Biology, University of Virginia, Charlottesville, VA, USA
}

\begin{abstract}
Early research on the direction of coiling (chirality) in snails had a prominent role in the history of biology, and continues to mold current thinking about developmental evolution. Here, we investigated the pleiotropic effects of chirality alleles on shell shape and length, using a large set of data from the Polynesian land snail Partula suturalis. By examining the shells of individuals with different combinations of their own and their mother's chiral genotypes, we find that the effects of chiral genes on length and shape involve both the maternal genotype and the genotype of the individual itself. Thus, differences in shape are symptoms of developmental shifts caused by the chirality alleles, or by
\end{abstract}

alleles at other loci in close linkage disequilibrium with them. Although changes in shell shape are not necessary concomitants of chiral evolution, the results illustrate the wider pleiotropic effects of the genes, or haplotypes, that influence chirality. As the data are a rare record of the association in nature between the phenotype and genotype of a locus showing maternal effects, the conclusions are likely to be relevant to the general understanding of the dynamics of maternal-effect genes, including how selection acts on them.

Heredity (2009) 103, 268-278; doi:10.1038/hdy.2009.49; published online 29 April 2009

Keywords: chirality; land snail; maternal inheritance; pleiotropy; shell shape

\section{Introduction}

When Boycott and Diver (1923) observed that shell coiling in the pond snail Lymnaea peregra is inherited, they found patterns of variation in the offspring that were difficult to understand, requiring a complicated model to fit the data. Sturtevant (1923) immediately postulated that these odd patterns happened because the expression of the coiling gene is delayed by a generation. After the necessary experiments were carried out, Sturtevant's 'inspired guess' (Boycott et al., 1930) proved to be correct. In all the species of pulmonate snails that have so far been examined, the chromosomal locus that determines asymmetry acts through the mother, so that the coil of a snail is determined by its mother's genes, not by its own, affecting the earliest stages of spiral cleavage. Consequently, with a few rare exceptions (Crampton, 1924), all the offspring from a single mother are identical in coil. The genotype and phenotype of a snail can be decoupled-individuals of the same chiral genotype can sometimes have opposite coils, and conversely, individuals with the same coil can have different chiral genotypes.

This early research on snail coiling has had an important role in the history of Mendelism (Gilbert, 1998). It is still a staple item in textbooks (Gilbert, 2006), and continues to mold current thinking (Gurdon, 2005; Wood, 2005; Levin and Palmer, 2007), yet progress in

Correspondence: Dr A Davison, Institute of Genetics, School of Biology, Queen's Medical Centre, University of Nottingham, University Park, Nottingham NG7 2RD, UK.

E-mail: angus.davison@nott.ac.uk

Received 16 December 2008; accepted 19 March 2009; published online 29 April 2009 understanding the establishment of molluscan asymmetry is limited to a few key papers since 1940 (Freeman and Lundelius, 1982; Shibazaki et al., 2004; Grande and Patel, 2008). This is unfortunate because, although the vast majority of molluscan species are dextral, sinistrals are found not only as isolated individuals, but also as whole populations, species and even families (Asami et al., 1998). Snails, like centipedes (Arthur, 1999), potentially offer an opportunity to understand how a generally conserved morphology can change, and how genes actually evolve when their action in the mother affects the phenotype of the offspring.

One intriguing finding has been that the maternal inheritance of chirality appears to be determined by a factor that the mother deposits in the unfertilized egg. When cytoplasm from dextral L. peregra embryos was injected into sinistral embryos, some of the receiving eggs then developed dextrally (Freeman and Lundelius, 1982). Unfortunately this work was not followed up. Of the more recent published work (Shibazaki et al., 2004; Hierck et al., 2005), the latter reported differences in cytoskeletal dynamics between dextral and sinistral embryos, implying that the molecular patterns of development in snails of different coil are not exact mirror images. This report echoes earlier observations based on shell morphology (Crampton, 1916, 1932).

So far, there has been only a single study of the pleiotropic effects of coiling genes (Johnson, 1987). It would indeed be extraordinary if alleles at the chirality locus, working so early in development, did not have effects beyond chirality itself. In the present work, which is based on a large sample from populations that are polymorphic for coil, we focus on the effects of chirality alleles on shell shape. 
Gould et al. (1985), using the snail Cerion, argued that any explanation for the rarity of sinistral snails must also consider the 'rules of form' because chirality and shell shape are changed together. The rarity of sinistrals might not be due to sinistrality itself but to a change in shape. Occasional aberrant sinistral individuals of Cerion, as well as sinistral snails at high frequencies in populations of Partula suturalis, tend to have relatively short and wide shells, so that both phenotypes (chirality and shell shape) must have evolved together. In contrast, Johnson (1987) found in $P$. suturalis that although an individual's coil is determined by the genotype of its mother, an individual's shape is largely determined by its own genotype. Johnson's field data showed no evidence of an association between maternal genotype and shell shape. He therefore argued that the two traits can evolve almost independently. An appreciation of their pleiotropic association would then be of relatively little value in understanding the evolution of sinistral snails.

A limitation of Johnson's study is that one of his two tables contained data from only three crosses (involving six hermaphrodite snails; in Johnson, 1987). The other table records four comparisons in small samples of snails from three populations (total $n=53$, in Johnson, 1987). Because the 'rules of form' in Partula are obviously important in trying to understand the evolution of chirality, as well as the more general impact of maternal effect genes, we decided to investigate the matter using a much larger set of data, based entirely on populations of $P$. suturalis collected in the field.

There is a potential for decoupling phenotype and genotype in genes with maternal effects, so it has been argued that they may evolve independently (Johnson, 1987), and that there may be time lags in their responses to selection, or even evolution in a direction opposite to that favored by selection (Kirkpatrick and Lande, 1989; Lande and Kirkpatrick, 1990). A general lack of attention to the details of heredity in genes with maternal effects is surprising, given their importance-for example, the early development of Drosophila is almost entirely controlled by maternal effect genes (Morisato and Anderson, 1995)—and the potential for complex pleiotropic effects. We consider that part of the explanation is that it is difficult to separate the later phenotypic effect of the maternal transcript and the individual's own transcript, especially if the effect is quantitative. In addition, loss-of-function mutations in maternal effect genes are most usually lethal.

In snails, there have been some models and simulations of the chirality-determining locus (Orr, 1991; van Batenburg and Gittenberger, 1996; Stone and Björklund, 2002; Davison et al., 2005), but there is a scarcity of empirical data. This is probably because dimorphic populations of snails are rare, but also because it is laborious to infer genotype from juvenile phenotypes when all the eggs that hatch from a female produce only a single data point. Therein lies the advantage of using $P$. suturalis because it is ovoviviparous. The coil of its intrauterine young indicates its genotype, and its own coil indicates the genotype of its mother. In addition, its shell size is known to be heritable (Murray and Clarke, 1968) and there is the possibility of maternal influences on shell shape within the uterus.

Here, we use more than 1500 P. suturalis from 32 populations to relate chirality phenotypes and genotypes to shell shape. The aim is to understand the precise relationship, and the general impact, if any, of shape changes on chiral evolution. The samples originate from a series of collections made during the 1960s and 1970s by BCC, JM and Michael Johnson as part of their general research on the adaptive radiation of Partula (Johnson et al., 1993), the genetics of the shell color/banding supergene (Murray and Clarke, 1976a,b), and of most relevance here, understanding the impact of chirality on speciation (Clarke and Murray, 1969; Johnson, 1982, 1987; Johnson et al., 1987, 1990). The samples were subsequently archived in the Natural History Museum (London), and so remain an excellent resource.

Note: to avoid confusion, we refer to an individual's coil phenotype (indicating its mother's genotype) in words (sinistral or sin, dextral or dex) and its own genotype (indicated by the coil of its intrauterine young) in italicized letters representing alternative alleles $(S, D)$. As the sinistral allele in $P$. suturalis is dominant over the dextral allele, five combinations of maternal and own genotypes are possible, sin $S D, \sin S S, \sin D D, \operatorname{dex} S D$ and dex $D D$. Sin $S D$ and sin $S S$ are indistinguishable because they both produce sinistral offspring. Dextral $S S$ homozygotes should not exist, except as rare aberrations (Crampton, 1924), because the mother would have to carry the dominant sinistral allele.

\section{Methods}

\section{Samples and measurements}

On the island of Moorea in the Society Islands, French Polynesia, purely sinistral and purely dextral populations of Partula are separated by steep clines of transition, between $\sim 0.5$ and $1 \mathrm{~km}$ wide (Johnson et al., 1993). For the present study, field samples of 32 populations (906 individual sinistral snails and 621 dextrals) were collected in 1962 and 1967 from different geographical locations, concentrating on the vicinity of mount Mouaroa (Figure 1). Each sample was restricted to a

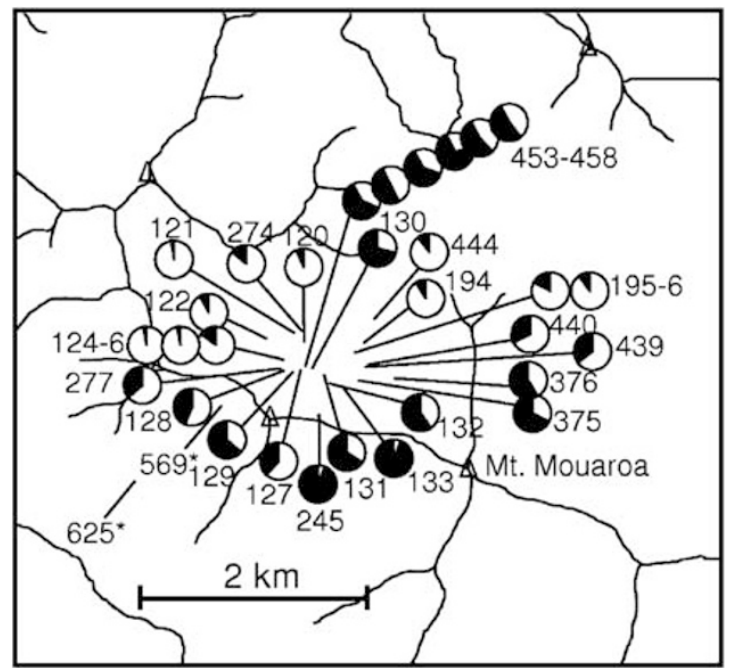

Figure 1 The location of the sample sites on Moorea, with the frequencies of sinistral (no shading) and dextral (black) snails. Lines indicate mountain ridges, with main summits labeled with triangles. Sites 569 and 625 are those used in the study by Johnson (1987). 


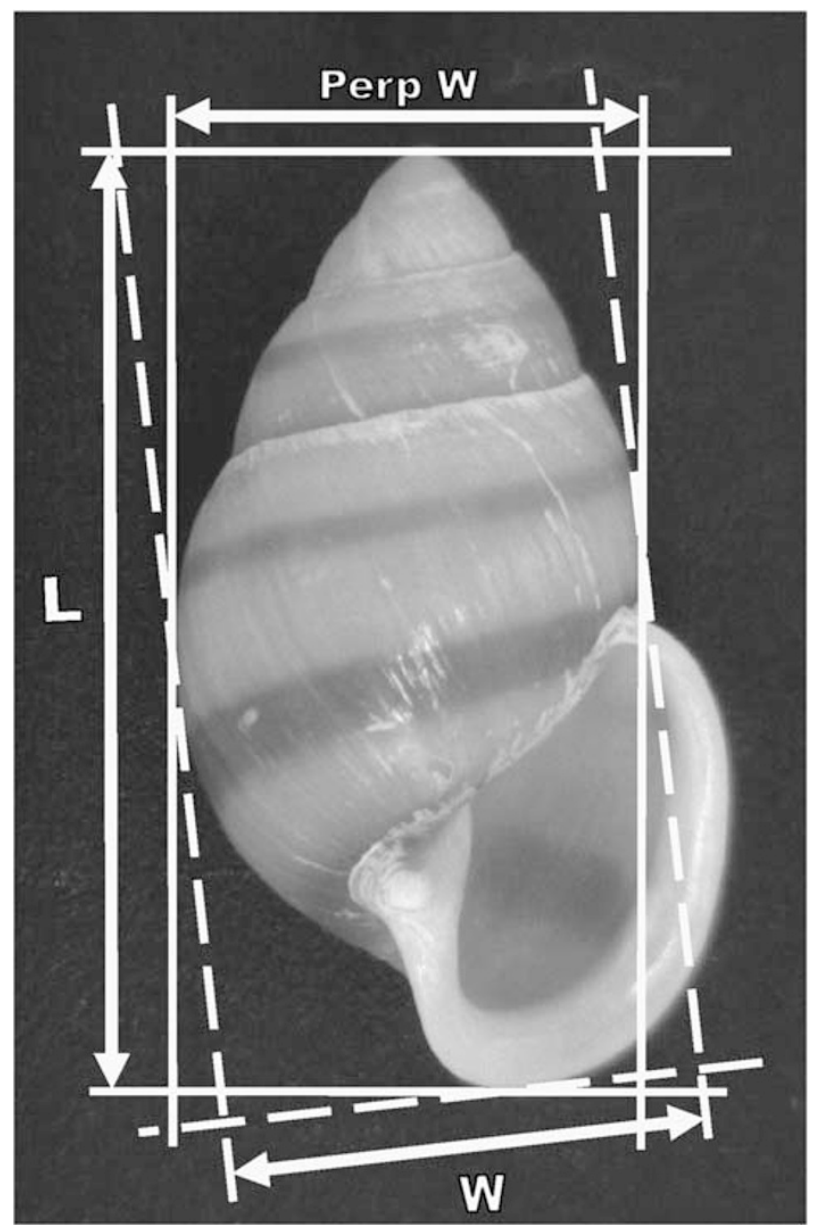

Figure 2 Measurements used in this study. 'Perp- $W$ ' is the width that is perpendicular to maximum length. It is not easily measured using calipers (Murray and Clarke, 1968).

$10 \times 10 \mathrm{~m}^{2}$. The detailed distributions of dextral and sinistral $P$. suturalis in this region have already been described (Clarke and Murray, 1969).

Two independent methods were used to take shell measurements. In the first, the length and width of shells from adult snails was measured to the nearest $0.1 \mathrm{~mm}$ using a set of vernier calipers (Murray and Clarke, 1968). Because the traditional measurement of width (perpendicular to length) is difficult to repeat reliably, 'width' was the distance between two lines that are tangent to the last two whorls, just proximal to the lip (Figure 2; Murray and Clarke, 1968). The shell width/length (w/1) ratio was then calculated as a proxy for shell shape, designated here as 'stoutness', after Crampton (1916). In the second method, we took a digital photograph of the shell, using a DinoLite 413T microscope (Anmo Electronics Corporation, Hsinchu, Taiwan), using calipers as a calibration (Figure 2). The image was then imported into ImageJ (http://rsbweb.nih.gov/ij/), sinistral shells were mirror-imaged and the same width and length measurements, as well as a third measure, the traditional width ('perp-W') were taken (Figure 2).

\section{Analyses}

The measurement of length may be more reproducible than width, because the angle at which the shell is measured could affect the width measurement, whereas the length can be measured without that complication. Separate analyses are therefore presented for length and stoutness. A possible problem is that the handedness of the measurer could influence the actual measurement, so a sample of snails was measured by both left- and righthanded people. In addition, sinistral snails were mirrorimaged for the digital photograph measures, removing any possibility of bias.

It is possible that presumed pleiotropic effects of the chirality genotype (that is, those except for coil) could either be inherited in a conventional Mendelian manner or be maternally determined like coil itself. As initial analyses show that length and stoutness are normally distributed in both sinistral and dextral shells, we looked for conventional Mendelian inheritance by comparing the shell length and stoutness (described by the w/1 ratio) of sinistral and dextral shells with the same chirality but different genotypes (for example, sin SD/ $S S$ versus $\sin D D$ ). To look for maternal inheritance, we compared the length and stoutness of shells with equivalent own genotypes but different maternal genotypes (for example, sin $S D / S S$ versus dex $S D$ ). These tests were first carried out within samples from individual populations. However, when it became clear that the effects on shape are subtle and sometimes apparently conflicting, we decided to combine data from several populations, improving the statistical power. To avoid uncontrolled biases, we used the same number of randomly selected snails from each population, examining differences in a pair-wise manner (for example, $n$ sin $S D / S S$ versus $n$ sin $D D$ ). To combine probabilities in a series of independent tests, we use the weighted- $Z$ method (Whitlock, 2005).

\section{Results}

\section{Preliminary analyses}

We started by assessing the errors in measuring the shells with vernier calipers. The lengths of shells were originally measured by Lorna Stewart, a technician at the University of Edinburgh. At that time widths were not obtained, for reasons of economy. In the present study, the length and width of each shell were measured by one of us (NC). As a result, we have 1480 repeated measures of length. The differences in length of dextrals as measured by NC and Lorna Stewart did not depart significantly from zero (mean difference $=0.007 \mathrm{~mm}$, $n=606$, s.e. $=0.0054$ ), but the length of sinistrals in the present study was greater by a small but significant margin $(0.018 \mathrm{~mm}, n=874$, s.e. $=0.0051, \quad P<0.001)$, perhaps indicating a slight bias by one or both persons.

All the subsequent analyses used the caliper measurements made by $\mathrm{NC}$, the justification being that as the prior expectation was that sinistrals should be shorter than dextrals, any bias by NC would be in the right direction (that is, against the expectation). Moreover it was desirable that the same person should measure both length and width, and in any case, the analyses (discussed below) showed that the mean difference in length between sinistrals and dextrals was $\sim 0.2 \mathrm{~mm}$, very much larger than the difference of $0.018 \mathrm{~mm}$ between measurements by NC and Lorna Stewart. 
Main analysis

First, we enquired if our material shows the same relations between chirality and shell shape as those that have already been reported (Crampton, 1916, 1932; Gould et al., 1985; Johnson, 1987). It does. In 22 of our samples with at least five snails of each phenotype (total $n$ sinistral $=598$, total $n$ dextral $=418$ ), the mean length of dextrals is greater in 18 comparisons, and the mean stoutness is less in 17 (Table 1). The ratios 18:4 and 17:5 differ significantly from $1: 1 \quad(P<0.0028$ and 0.0105 , respectively, by the binomial test). Within individual samples, four comparisons of length are statistically significant, as are seven comparisons of stoutness, although one of the latter (population 277) is in the direction opposite to that expected (Figure 3a). Combining probabilities using the powerful weighted- $Z$ method (Whitlock, 2005), we find the overall trends very highly significant ( $P<0.001$ for both length and stoutness). Over all the populations, the average length of the dextrals is $0.258 \pm 0.080 \mathrm{~mm}$ greater than that of the sinistrals, and the average stoutness of the sinistrals is $1.015 \pm 0.005$ (s.e.) times greater than that of the dextrals. The equivalent stoutness ratio in Johnson's (1987) study was $1.026 \pm 0.005$. The overall trend is thus the same. The magnitude in our study is smaller but not significantly so.

To investigate whether a snail's own coiling genotype affects the length or stoutness, we compared 'genetically sinistral' snails $(S D, S S)$ with 'genetically dextral' snails $(D D)$, regardless of their actual coil. In 16 population samples with at least five snails of each genotype (total $n$ of $S D$ and $S S=361$, total $n$ of $D D=258$ ), the mean length of snails with dextral genotypes is greater in 14 comparisons, and their mean stoutness is lower in 12

Table 1 Associations of phenotype with length and w/1 ratio across 22 populations

\begin{tabular}{|c|c|c|c|c|c|c|c|c|c|c|}
\hline \multirow[t]{2}{*}{ Site } & & \multirow[t]{2}{*}{$\mathrm{N}$} & \multicolumn{4}{|c|}{ Length } & \multicolumn{4}{|c|}{ Width/Length } \\
\hline & & & Mean & s.e. & $\mathrm{t}$ & $\mathrm{P}$ & Mean & s.e. & $t$ & $\mathrm{P}$ \\
\hline \multirow[t]{2}{*}{120} & Dextral & 7 & 19.51 & 0.31 & -0.06 & 0.954 & 0.494 & 0.005 & -0.23 & 0.818 \\
\hline & Sinistral & 94 & 19.53 & 0.08 & & & 0.496 & 0.002 & & \\
\hline \multirow[t]{2}{*}{126} & Dextral & 5 & 19.66 & 0.37 & -0.15 & 0.884 & 0.504 & 0.008 & 0.46 & 0.646 \\
\hline & Sinistral & 29 & 19.71 & 0.14 & & & 0.500 & 0.003 & & \\
\hline \multirow[t]{2}{*}{127} & Dextral & 5 & 20.58 & 0.45 & 1.55 & 0.149 & 0.488 & 0.005 & -2.74 & $0.019^{*}$ \\
\hline & Sinistral & 8 & 19.89 & 0.22 & & & 0.506 & 0.004 & & \\
\hline \multirow[t]{2}{*}{128} & Dextral & 25 & 19.78 & 0.19 & 1.03 & 0.309 & 0.497 & 0.006 & -1.09 & 0.282 \\
\hline & Sinistral & 27 & 19.54 & 0.14 & & & 0.505 & 0.004 & & \\
\hline \multirow[t]{2}{*}{129} & Dextral & 12 & 19.38 & 0.25 & -1.51 & 0.149 & 0.494 & 0.005 & 0.10 & 0.920 \\
\hline & Sinistral & 7 & 20.03 & 0.37 & & & 0.493 & 0.010 & & \\
\hline \multirow[t]{2}{*}{130} & Dextral & 31 & 19.21 & 0.12 & 0.34 & 0.737 & 0.506 & 0.003 & -2.90 & $0.006^{* *}$ \\
\hline & Sinistral & 13 & 19.13 & 0.23 & & & 0.525 & 0.006 & & \\
\hline \multirow[t]{2}{*}{131} & Dextral & 25 & 19.67 & 0.17 & 2.47 & $0.018^{*}$ & 0.491 & 0.004 & -3.75 & $0.001^{* *}$ \\
\hline & Sinistral & 14 & 18.93 & 0.27 & & & 0.518 & 0.007 & & \\
\hline \multirow[t]{2}{*}{132} & Dextral & 57 & 19.78 & 0.10 & 1.45 & 0.151 & 0.506 & 0.003 & -0.40 & 0.688 \\
\hline & Sinistral & 42 & 19.56 & 0.11 & & & 0.507 & 0.003 & & \\
\hline \multirow[t]{2}{*}{196} & Dextral & 7 & 19.41 & 0.28 & 0.77 & 0.443 & 0.499 & 0.007 & -0.98 & 0.330 \\
\hline & Sinistral & 64 & 19.16 & 0.11 & & & 0.505 & 0.002 & & \\
\hline \multirow[t]{2}{*}{274} & Dextral & 8 & 19.28 & 0.13 & -1.38 & 0.174 & 0.500 & 0.006 & 0.60 & 0.550 \\
\hline & Sinistral & 49 & 19.59 & 0.09 & & & 0.496 & 0.003 & & \\
\hline \multirow[t]{2}{*}{277} & Dextral & 15 & 19.39 & 0.18 & 0.05 & 0.961 & 0.507 & 0.004 & 2.48 & $0.018^{*}$ \\
\hline & Sinistral & 27 & 19.38 & 0.15 & & & 0.493 & 0.003 & & \\
\hline \multirow[t]{2}{*}{375} & Dextral & 25 & 19.60 & 0.16 & 1.63 & 0.113 & 0.501 & 0.004 & -2.64 & $0.012^{*}$ \\
\hline & Sinistral & 12 & 19.07 & 0.34 & & & 0.521 & 0.006 & & \\
\hline \multirow[t]{2}{*}{376} & Dextral & 22 & 19.56 & 0.20 & 0.59 & 0.558 & 0.503 & 0.004 & -0.19 & 0.852 \\
\hline & Sinistral & 14 & 19.37 & 0.27 & & & 0.504 & 0.006 & & \\
\hline \multirow[t]{2}{*}{439} & Dextral & 6 & 20.02 & 0.48 & 0.79 & 0.440 & 0.488 & 0.007 & -0.68 & 0.504 \\
\hline & Sinistral & 11 & 19.69 & 0.16 & & & 0.493 & 0.004 & & \\
\hline \multirow[t]{2}{*}{440} & Dextral & 11 & 19.15 & 0.17 & 0.71 & 0.480 & 0.490 & 0.004 & -1.98 & 0.055 \\
\hline & Sinistral & 25 & 18.97 & 0.15 & & & 0.500 & 0.003 & & \\
\hline \multirow[t]{2}{*}{444} & Dextral & 5 & 19.80 & 0.26 & 0.33 & 0.742 & 0.486 & 0.006 & -2.24 & $0.030^{*}$ \\
\hline & Sinistral & 44 & 19.67 & 0.13 & & & 0.504 & 0.003 & & \\
\hline \multirow[t]{2}{*}{453} & Dextral & 42 & 18.62 & 0.15 & 2.57 & $0.012^{*}$ & 0.507 & 0.004 & -0.82 & 0.414 \\
\hline & Sinistral & 28 & 18.09 & 0.13 & & & 0.513 & 0.004 & & \\
\hline 454 & Dextral & 29 & 18.84 & 0.13 & 2.00 & 0.051 & 0.499 & 0.004 & -1.11 & 0.270 \\
\hline & Sinistral & 29 & 18.46 & 0.14 & & & 0.505 & 0.003 & & \\
\hline 455 & Dextral & 21 & 18.63 & 0.15 & 0.42 & 0.680 & 0.515 & 0.005 & 0.71 & 0.486 \\
\hline & Sinistral & 13 & 18.52 & 0.24 & & & 0.510 & 0.004 & & \\
\hline 456 & Dextral & 11 & 18.66 & 0.27 & 2.57 & $0.022^{*}$ & 0.511 & 0.007 & -0.43 & 0.671 \\
\hline & Sinistral & 5 & 17.54 & 0.22 & & & 0.517 & 0.013 & & \\
\hline 457 & Dextral & 19 & 19.28 & 0.11 & 3.13 & $0.004^{* *}$ & 0.493 & 0.004 & -5.55 & $<0.001^{* * *}$ \\
\hline & Sinistral & 16 & 18.59 & 0.20 & & & 0.523 & 0.004 & & \\
\hline 458 & Dextral & 30 & 18.33 & 0.14 & 1.29 & 0.201 & 0.505 & 0.003 & -0.76 & 0.449 \\
\hline & Sinistral & 27 & 18.06 & 0.15 & & & 0.509 & 0.004 & & \\
\hline
\end{tabular}

*Significant difference by two-tailed $t$-test, $P<0.05$; ${ }^{* *} P<0.01$, ${ }^{* * *} P<0.001$. Comparisons in the expected direction (sinistrals shorter but stouter) are indicated by a bold $t$-value. 


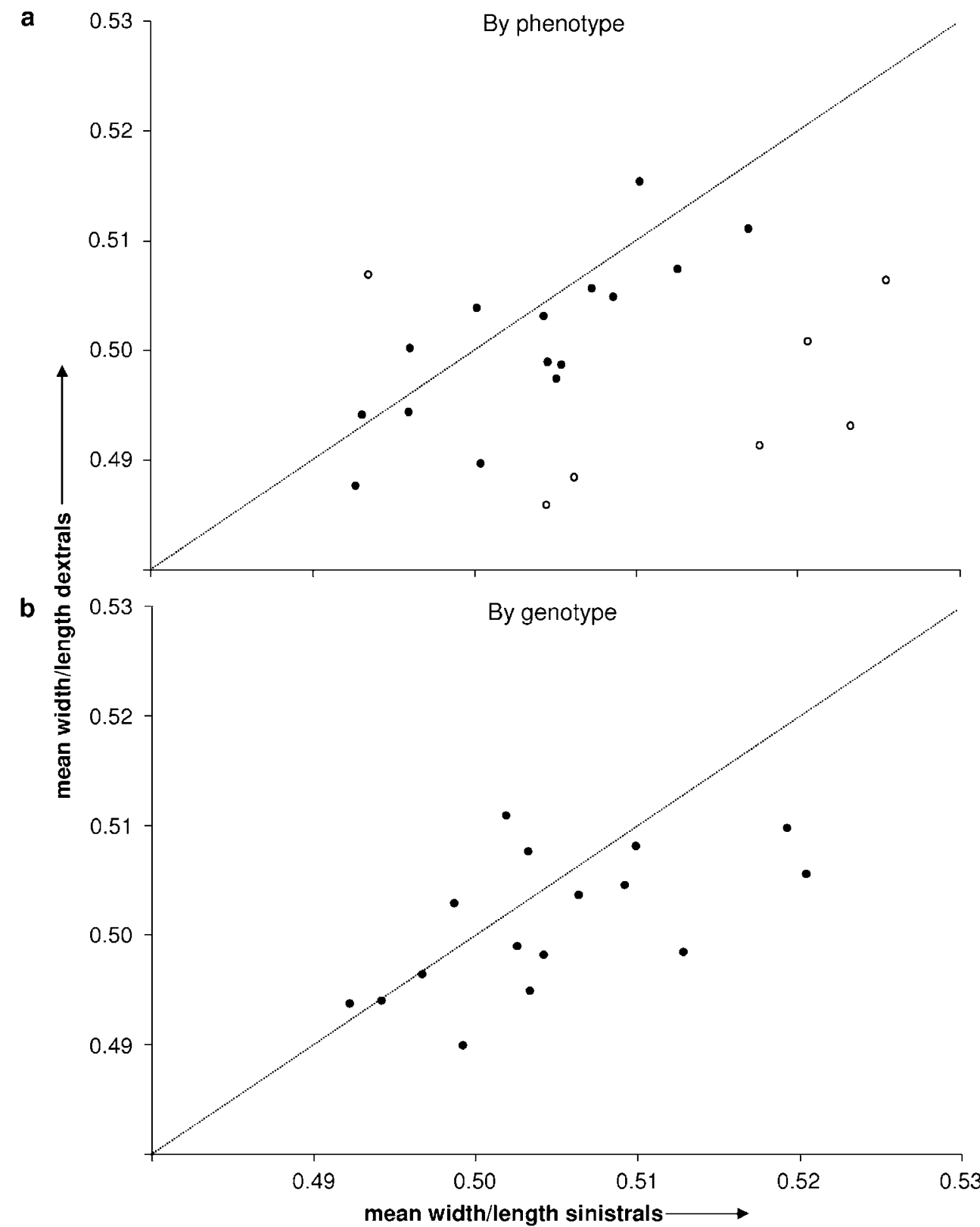

Figure 3 Comparison of (a) the mean ratio of shell width to length sinistral and dextral P. suturalis in each of 22 populations and (b) the mean ratio of shell width to length in genetically sinistral $(S D, S S)$ and dextral $(D D)$ P. suturalis in each of 16 populations. There is a large deviation from equality when comparing phenotypes (a), but no trend when comparing genotypes. As in of Johnson (1987), the diagonal line represents the ratio expected if there is no difference between dextrals and sinistrals. Open circles represent significant departures from equality.

(Table 2). The ratios 14:2 and 12:4 are significantly different from 1:1 $(P<0.002$ and $<0.046$, respectively, using the binomial test). Within individual populations, the differences in length are significant in two cases, but the differences in stoutness are significant in none (Figure $3 b$ ). The more powerful weighted- $Z$ method shows that, overall, 'genetic dextrals' are very significantly longer $(P<0.0001)$ and less stout $(P<0.015)$ than 'genetic sinistrals'.

Although maternally inherited characters allow a decoupling between genotype and phenotype, the two are not expected to be independent, particularly because snails are more likely to mate with others of the same coil (Lipton and Murray, 1979; Asami et al., 1998). The observations reported above will be imperfectly controlled if in the first analysis phenotypic sinistrals are more likely to contain sinistral alleles (that is, be $S D$ or $S S$ ) and if in the second analysis genetic sinistrals (SD or $S S$ ) are more likely to be sinistral rather than dextral in coil. When the association was tested by comparing the proportion of a particular phenotype within a population to the proportion of its relevant genotype there was indeed, as expected, a very strong and significant correlation (Figure $4 ; P<0.0001 ; r^{2}=0.875$ ). Our analyses were therefore refined by simultaneously examining combinations of coiling phenotypes and genotypes, and comparing their lengths and stoutness.

The first such analysis examined the effects of different genotypes on the length and stoutness of snails with the same coiling phenotype. The strong associations shown 
Table 2 Associations of genotype with length and w/1 ratio across 16 populations

\begin{tabular}{|c|c|c|c|c|c|c|c|c|c|c|}
\hline \multirow[t]{2}{*}{ Site } & & \multirow[t]{2}{*}{$\mathrm{N}$} & \multicolumn{4}{|c|}{ Length } & \multicolumn{4}{|c|}{ Width/Length } \\
\hline & & & Mean & s.e. & $\mathrm{t}$ & $\mathrm{P}$ & Mean & s.e. & $t$ & $\mathrm{P}$ \\
\hline \multirow[t]{2}{*}{120} & $D D$ & 7 & 19.79 & 0.36 & 0.73 & 0.465 & 0.494 & 0.009 & -0.04 & 0.969 \\
\hline & $S D / S S$ & 69 & 19.55 & 0.10 & & & 0.494 & 0.002 & & \\
\hline \multirow[t]{2}{*}{128} & $D D$ & 19 & 19.87 & 0.17 & 0.62 & 0.542 & 0.499 & 0.006 & -0.53 & 0.602 \\
\hline & $S D / S S$ & 20 & 19.72 & 0.18 & & & 0.503 & 0.004 & & \\
\hline \multirow[t]{2}{*}{129} & $D D$ & 10 & 19.77 & 0.28 & 0.49 & 0.634 & 0.494 & 0.006 & 0.13 & 0.896 \\
\hline & $S D / S S$ & 6 & 19.52 & 0.50 & & & 0.492 & 0.011 & & \\
\hline \multirow[t]{2}{*}{130} & $D D$ & 31 & 19.25 & 0.11 & -0.30 & 0.764 & 0.510 & 0.003 & -1.16 & 0.253 \\
\hline & $S D / S S$ & 7 & 19.33 & 0.34 & & & 0.519 & 0.009 & & \\
\hline \multirow[t]{2}{*}{132} & $D D$ & 38 & 19.88 & 0.09 & 2.63 & $0.010^{*}$ & 0.505 & 0.003 & -1.06 & 0.294 \\
\hline & $S D / S S$ & 42 & 19.46 & 0.13 & & & 0.509 & 0.003 & & \\
\hline \multirow[t]{2}{*}{274} & $D D$ & 9 & 19.44 & 0.21 & -0.32 & 0.748 & 0.503 & 0.006 & 0.64 & 0.538 \\
\hline & $S D / S S$ & 39 & 19.52 & 0.10 & & & 0.499 & 0.003 & & \\
\hline \multirow[t]{2}{*}{277} & $D D$ & 12 & 19.42 & 0.18 & 0.40 & 0.693 & 0.496 & 0.005 & -0.06 & 0.953 \\
\hline & $S D / S S$ & 22 & 19.31 & 0.17 & & & 0.497 & 0.004 & & \\
\hline \multirow[t]{2}{*}{375} & $D D$ & 24 & 19.62 & 0.18 & 1.95 & 0.061 & 0.505 & 0.004 & -1.74 & 0.092 \\
\hline & $S D / S S$ & 7 & 18.86 & 0.40 & & & 0.520 & 0.008 & & \\
\hline \multirow[t]{2}{*}{376} & $D D$ & 15 & 19.61 & 0.25 & 0.91 & 0.372 & 0.508 & 0.005 & 0.57 & 0.573 \\
\hline & $S D / S S$ & 13 & 19.28 & 0.26 & & & 0.503 & 0.005 & & \\
\hline \multirow[t]{2}{*}{440} & $D D$ & 9 & 19.10 & 0.19 & 0.18 & 0.855 & 0.490 & 0.004 & -1.55 & 0.133 \\
\hline & $S D / S S$ & 21 & 19.05 & 0.17 & & & 0.499 & 0.004 & & \\
\hline \multirow[t]{2}{*}{444} & $D D$ & 10 & 19.73 & 0.28 & 0.17 & 0.869 & 0.495 & 0.008 & -1.34 & 0.187 \\
\hline & $S D / S S$ & 36 & 19.68 & 0.14 & & & 0.503 & 0.003 & & \\
\hline \multirow[t]{2}{*}{453} & $D D$ & 26 & 18.72 & 0.16 & 2.98 & $0.005^{* *}$ & 0.498 & 0.005 & -1.94 & 0.059 \\
\hline & $S D / S S$ & 20 & 18.02 & 0.16 & & & 0.513 & 0.005 & & \\
\hline \multirow[t]{2}{*}{454} & $D D$ & 10 & 19.01 & 0.23 & 1.17 & 0.255 & 0.498 & 0.007 & -0.74 & 0.465 \\
\hline & $S D / S S$ & 16 & 18.63 & 0.21 & & & 0.504 & 0.005 & & \\
\hline \multirow[t]{2}{*}{455} & $D D$ & 14 & 18.75 & 0.21 & 0.10 & 0.922 & 0.511 & 0.007 & 0.89 & 0.387 \\
\hline & $S D / S S$ & 7 & 18.71 & 0.30 & & & 0.502 & 0.005 & & \\
\hline \multirow[t]{2}{*}{457} & $D D$ & 10 & 19.14 & 0.20 & 0.32 & 0.749 & 0.508 & 0.006 & -0.21 & 0.833 \\
\hline & $S D / S S$ & 16 & 19.05 & 0.18 & & & 0.510 & 0.006 & & \\
\hline \multirow[t]{2}{*}{458} & $D D$ & 14 & 18.56 & 0.24 & 1.02 & 0.313 & 0.504 & 0.005 & -0.41 & 0.683 \\
\hline & $S D / S S$ & 20 & 18.27 & 0.17 & & & 0.506 & 0.005 & & \\
\hline
\end{tabular}

*Significant difference by two-tailed $t$-test, $P<0.05$; ${ }^{*} P<0.01$. Comparisons in the expected direction (sinistrals shorter but stouter) are indicated by a bold $t$-value.

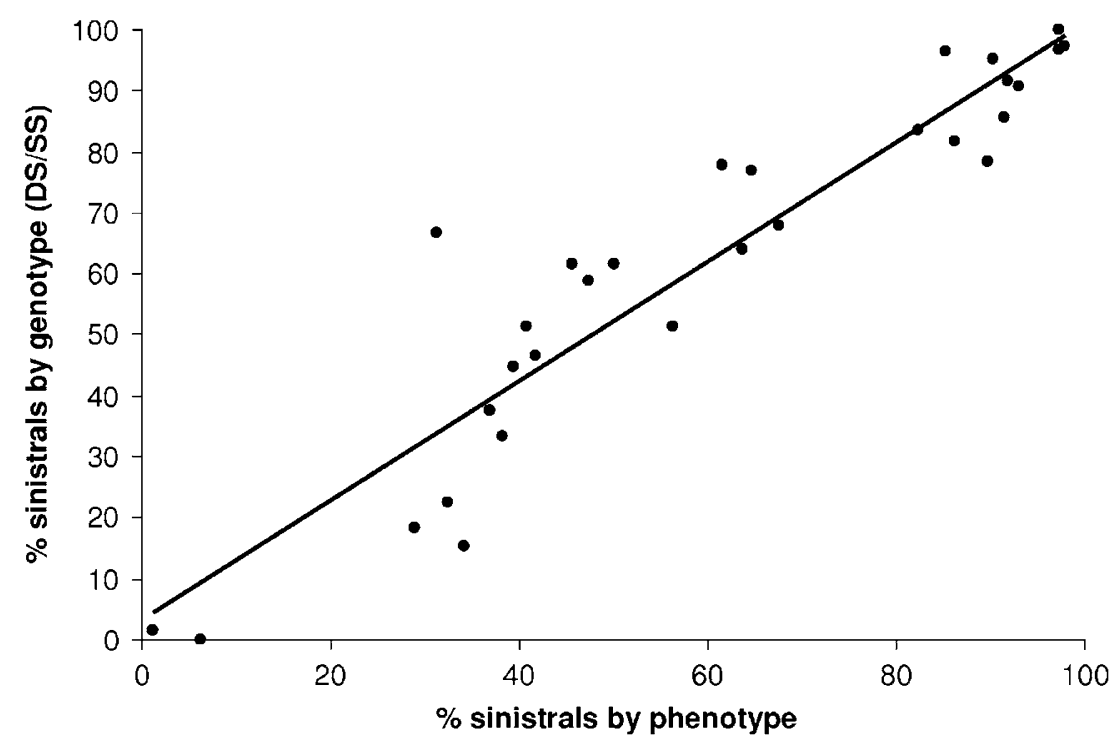

Figure 4 Relationship between shell chirality and individual genotype $\left(b=0.978, r^{2}=0.875, P<0.0001\right)$.

in Figure 4 result in some phenotype-genotype combinations being rare, so that only nine valid comparisons are possible (Table 3), testing a total of 73 dextral $D D$ snails against 35 dextral $S D$, and 31 sinistral $D D$ against 150 sinistral SD/SS. Eight of the nine comparisons show that genetically dextral snails are longer than genetically sinistral ones (this 8:1 ratio significantly departs from 1:1 in the expected direction $P<0.05)$. They are less stout in 
Table 3 Associations of genotype with length and w/l ratio across 9 populations, controlled by phenotype

\begin{tabular}{|c|c|c|c|c|c|c|c|c|c|c|c|}
\hline & \multirow[t]{2}{*}{ Site } & & \multirow[t]{2}{*}{$\mathrm{N}$} & \multicolumn{4}{|c|}{ Length } & \multicolumn{4}{|c|}{ Width/Length } \\
\hline & & & & Mean & s.e. & $\mathrm{t}$ & $\mathrm{P}$ & Mean & s.e. & $\mathrm{t}$ & $\mathrm{P}$ \\
\hline \multirow[t]{8}{*}{ Controls for dextral phenotype } & \multirow[t]{2}{*}{132} & $\operatorname{dex} D D$ & 31 & 19.92 & 0.11 & \multirow[t]{2}{*}{1.68} & \multirow[t]{2}{*}{0.100} & 0.507 & 0.004 & \multirow[t]{2}{*}{0.08} & \multirow[t]{2}{*}{0.933} \\
\hline & & $\operatorname{dex} S D$ & 15 & 19.51 & 0.27 & & & 0.506 & 0.005 & & \\
\hline & \multirow[t]{2}{*}{453} & $\operatorname{dex} D D$ & 22 & 18.77 & 0.18 & \multirow[t]{2}{*}{0.35} & \multirow[t]{2}{*}{0.731} & 0.499 & 0.006 & \multirow[t]{2}{*}{-0.04} & \multirow[t]{2}{*}{0.969} \\
\hline & & $\operatorname{dex} S D$ & 6 & 18.63 & 0.33 & & & 0.500 & 0.011 & & \\
\hline & \multirow[t]{2}{*}{457} & $\operatorname{dex} D D$ & 7 & 19.30 & 0.15 & \multirow[t]{2}{*}{0.13} & \multirow[t]{2}{*}{0.900} & 0.500 & 0.006 & \multirow[t]{2}{*}{0.70} & \multirow[t]{2}{*}{0.499} \\
\hline & & $\operatorname{dex} S D$ & 8 & 19.26 & 0.24 & & & 0.493 & 0.006 & & \\
\hline & \multirow[t]{2}{*}{458} & $\operatorname{dex} D D$ & 13 & 18.64 & 0.24 & \multirow[t]{2}{*}{0.45} & \multirow[t]{2}{*}{0.662} & 0.504 & 0.005 & \multirow[t]{2}{*}{0.53} & \multirow[t]{2}{*}{0.603} \\
\hline & & $\operatorname{dex} S D$ & 6 & 18.47 & 0.20 & & & 0.499 & 0.005 & & \\
\hline \multirow[t]{10}{*}{ Controls for sinistral phenotype } & \multirow[t]{2}{*}{120} & $\sin D D$ & 6 & 19.63 & 0.39 & \multirow[t]{2}{*}{0.16} & \multirow[t]{2}{*}{0.873} & 0.496 & 0.011 & \multirow[t]{2}{*}{0.20} & \multirow[t]{2}{*}{0.846} \\
\hline & & $\sin S D / S S$ & 65 & 19.58 & 0.10 & & & 0.494 & 0.003 & & \\
\hline & \multirow[t]{2}{*}{130} & $\sin D D$ & 5 & 19.04 & 0.31 & \multirow[t]{2}{*}{-1.02} & 0.334 & 0.519 & 0.009 & -0.30 & 0.773 \\
\hline & & $\sin S D / S S$ & 6 & 19.52 & 0.34 & & & 0.523 & 0.009 & & \\
\hline & 132 & $\sin D D$ & 7 & 19.74 & 0.19 & 1.09 & 0.286 & 0.494 & 0.006 & -2.16 & $0.039 *$ \\
\hline & & $\sin S D / S S$ & 27 & 19.43 & 0.14 & & & 0.511 & 0.004 & & \\
\hline & 277 & $\sin D D$ & 5 & 19.50 & 0.26 & 0.56 & 0.585 & 0.490 & 0.008 & -0.68 & 0.506 \\
\hline & & $\sin S D / S S$ & 19 & 19.28 & 0.19 & & & 0.495 & 0.004 & & \\
\hline & 444 & $\sin D D$ & 8 & 19.84 & 0.33 & 0.58 & 0.564 & 0.499 & 0.009 & -0.73 & 0.467 \\
\hline & & $\sin S D / S S$ & 33 & 19.64 & 0.15 & & & 0.504 & 0.003 & & \\
\hline
\end{tabular}

*Significant difference by two-tailed $t$-test, $P<0.05$. Comparisons in the expected direction (sinistrals shorter but stouter) are indicated by a bold $t$-value.

Table 4 Associations of phenotype with length and w/1 ratio across nine populations, controlled by genotype

\begin{tabular}{|c|c|c|c|c|c|c|c|c|c|c|c|}
\hline & \multirow[t]{2}{*}{ Site } & & \multirow[t]{2}{*}{$\mathrm{N}$} & \multicolumn{4}{|c|}{ Length } & \multicolumn{4}{|c|}{ Width/Length } \\
\hline & & & & Mean & s.e. & $\mathrm{t}$ & $\mathrm{P}$ & Mean & s.e. & $\mathrm{t}$ & $\mathrm{P}$ \\
\hline \multirow[t]{6}{*}{ Controls for dextral genotype } & \multirow[t]{2}{*}{130} & $\operatorname{dex} D D$ & 25 & 19.29 & 0.11 & \multirow[t]{2}{*}{0.88} & \multirow[t]{2}{*}{0.388} & 0.508 & 0.004 & \multirow[t]{2}{*}{-1.30} & \multirow[t]{2}{*}{0.205} \\
\hline & & $\sin D D$ & 5 & 19.04 & 0.31 & & & 0.519 & 0.009 & & \\
\hline & \multirow[t]{2}{*}{132} & $\operatorname{dex} D D$ & 31 & 19.92 & 0.11 & \multirow[t]{2}{*}{0.71} & \multirow{2}{*}{0.480} & 0.507 & 0.004 & \multirow[t]{2}{*}{1.61} & \multirow{2}{*}{0.116} \\
\hline & & $\sin D D$ & 7 & 19.74 & 0.19 & & & 0.494 & 0.006 & & \\
\hline & \multirow[t]{2}{*}{277} & $\operatorname{dex} D D$ & 7 & 19.36 & 0.25 & \multirow[t]{2}{*}{-0.39} & \multirow[t]{2}{*}{0.708} & 0.501 & 0.006 & \multirow[t]{2}{*}{1.22} & \multirow[t]{2}{*}{0.251} \\
\hline & & $\sin D D$ & 5 & 19.50 & 0.26 & & & 0.490 & 0.007 & & \\
\hline \multirow[t]{8}{*}{ Controls for sinistral genotype } & \multirow[t]{2}{*}{132} & $\operatorname{dex} S D$ & 15 & 19.51 & 0.27 & \multirow[t]{2}{*}{0.31} & \multirow[t]{2}{*}{0.759} & 0.506 & 0.005 & \multirow[t]{2}{*}{-0.68} & \multirow[t]{2}{*}{0.499} \\
\hline & & $\sin S D / S S$ & 27 & 19.43 & 0.14 & & & 0.511 & 0.004 & & \\
\hline & \multirow[t]{2}{*}{453} & $\operatorname{dex} S D$ & 6 & 18.63 & 0.33 & \multirow[t]{2}{*}{2.89} & \multirow[t]{2}{*}{$0.010^{* *}$} & 0.500 & 0.011 & \multirow[t]{2}{*}{-1.74} & \multirow{2}{*}{0.100} \\
\hline & & $\sin S D / S S$ & 14 & 17.76 & 0.14 & & & 0.518 & 0.005 & & \\
\hline & \multirow[t]{2}{*}{457} & $\operatorname{dex} S D$ & 8 & 19.26 & 0.24 & \multirow[t]{2}{*}{1.18} & \multirow[t]{2}{*}{0.257} & 0.493 & 0.006 & \multirow[t]{2}{*}{-4.18} & $0.001^{* *}$ \\
\hline & & $\sin S D / S S$ & 8 & 18.84 & 0.27 & & & 0.527 & 0.005 & & \\
\hline & 458 & $\operatorname{dex} S D$ & 6 & 18.47 & 0.20 & 0.76 & 0.454 & 0.499 & 0.005 & -1.03 & 0.317 \\
\hline & & $\sin S D / S S$ & 14 & 18.18 & 0.23 & & & 0.509 & 0.006 & & \\
\hline
\end{tabular}

**Significant difference by two-tailed $t$-test, $P<0.01$. Comparisons in the expected direction (sinistrals shorter but stouter) are indicated by bold $t$-values.

five out of nine comparisons (which does not depart significantly from 1:1). There is only one significant comparison within a single population (stoutness in population 132). Using the weighted- $Z$ method, however, we observe that the four combined probabilities of dextral $D D$ versus dextral $S D$ snails are very nearly significant by themselves $(P<0.051)$. Over the four dextral populations, the average length of $D D$ snails is $0.185 \mathrm{~mm}( \pm 0.077)$ greater than $S D$ snails. Sinistral $D D$ snails are $0.060 \mathrm{~mm}( \pm 0.141)$ longer than sinistral $S D / S S$ snails. In contrast, the stoutness of $S D$ snails in the four dextral populations is slightly less than that of $D D$ snails $(0.994 \pm 0.003)$, but among the sinistrals, $S D / S S$ snails are $1.012 \pm 0.006$ times stouter than $D D$, in accordance with expectation.
A second analysis examined the effects of different coiling phenotypes on the length and stoutness of snails with the same coil genotype. We were able to use seven populations. We compared 61 dextral $D D$ snails with 17 sinistral $D D$ snails, and 35 dextral $S D$ snails with 63 sinistral SD/SS snails (Table 4). Snails of dextral phenotype with the genotype $D D$ are longer than sinistrals of the same genotype. The same is true for the genotypes $S D / S S$. Thus the results match expectations in six out of seven comparisons. They are slimmer in five out of seven comparisons. A single comparison (453) shows a significant difference between the lengths of dextral and sinistral snails and another (457) shows a significant difference in stoutness. Using the weighted- $Z$ method to combine probabilities, we found that dextral 
Table 5 Combined analysis using all possible comparisons

\begin{tabular}{|c|c|c|c|c|c|c|c|c|c|c|c|}
\hline \multirow[t]{2}{*}{ Comparison } & \multirow[t]{2}{*}{ Phenotype } & \multirow[t]{2}{*}{ Genotype } & \multirow[t]{2}{*}{$\mathrm{N}$} & \multicolumn{4}{|c|}{ Length } & \multicolumn{4}{|c|}{ Width/Length } \\
\hline & & & & Mean & s.e. & $\mathrm{t}$ & $\mathrm{P}$ & Mean & s.e. & $\mathrm{t}$ & $\mathrm{P}$ \\
\hline \multirow[t]{2}{*}{ 1. Controls for phenotype } & Dextral & $D D$ & 67 & 19.54 & 0.10 & \multirow[t]{2}{*}{2.22} & \multirow[t]{2}{*}{$0.030^{*}$} & 0.500 & 0.002 & \multirow[t]{2}{*}{-0.26} & \multirow[t]{2}{*}{0.798} \\
\hline & Dextral & $S D$ & 67 & 19.26 & 0.11 & & & 0.501 & 0.002 & & \\
\hline \multirow[t]{2}{*}{ 2. Controls for phenotype } & Sinistral & $D D$ & 71 & 19.39 & 0.11 & \multirow[t]{2}{*}{0.36} & \multirow[t]{2}{*}{0.719} & 0.503 & 0.002 & \multirow[t]{2}{*}{-1.16} & \multirow[t]{2}{*}{0.249} \\
\hline & Sinistral & $S D / S S$ & 71 & 19.33 & 0.12 & & & 0.508 & 0.003 & & \\
\hline \multirow[t]{2}{*}{ 3. Controls for genotype } & Dextral & $D D$ & 57 & 19.47 & 0.12 & \multirow[t]{2}{*}{1.23} & \multirow[t]{2}{*}{0.226} & 0.498 & 0.003 & \multirow[t]{2}{*}{-1.24} & \multirow[t]{2}{*}{0.222} \\
\hline & Sinistral & $D D$ & 57 & 19.45 & 0.12 & & & 0.502 & 0.003 & & \\
\hline \multirow[t]{2}{*}{ 4. Controls for genotype } & Dextral & $S D$ & 83 & 19.31 & 0.10 & \multirow[t]{2}{*}{1.03} & \multirow[t]{2}{*}{0.307} & 0.499 & 0.002 & \multirow[t]{2}{*}{-3.33} & \multirow[t]{2}{*}{$0.001^{* *}$} \\
\hline & Sinistral & $S D / S S$ & 83 & 19.18 & 0.11 & & & 0.508 & 0.002 & & \\
\hline
\end{tabular}

*Significant difference by paired $t$-test, $P<0.05 ;{ }^{* *} P<0.01$. Comparisons in the expected direction (sinistrals shorter but stouter) are indicated by a bold $t$-value.

Table 6 Associations of length and $\mathrm{w} / \mathrm{l}$ ratio in phenotypically and genetically different snails

\begin{tabular}{|c|c|c|c|c|c|c|c|c|c|c|}
\hline \multirow[t]{2}{*}{ Site } & & \multirow[t]{2}{*}{$\mathrm{N}$} & \multicolumn{4}{|c|}{ Length } & \multicolumn{4}{|c|}{ Width/Length } \\
\hline & & & Mean & s.e. & $\mathrm{t}$ & $\mathrm{P}$ & Mean & s.e. & $\mathrm{t}$ & $\mathrm{P}$ \\
\hline \multirow[t]{2}{*}{128} & $\operatorname{dex} D D$ & 15 & 20.04 & 0.19 & 1.40 & 0.171 & 0.494 & 0.006 & -1.46 & 0.155 \\
\hline & $\sin S D / S S$ & 19 & 19.67 & 0.18 & & & 0.505 & 0.004 & & \\
\hline \multirow[t]{2}{*}{130} & $\operatorname{dex} D D$ & 25 & 19.29 & 0.11 & -0.82 & 0.418 & 0.508 & 0.004 & -1.82 & 0.079 \\
\hline & $\sin S D / S S$ & 6 & 19.52 & 0.34 & & & 0.523 & 0.009 & & \\
\hline \multirow[t]{2}{*}{132} & $\operatorname{dex} D D$ & 31 & 19.92 & 0.11 & 2.83 & $0.007^{* *}$ & 0.507 & 0.004 & -0.73 & 0.467 \\
\hline & $\sin S D / S S$ & 27 & 19.43 & 0.14 & & & 0.511 & 0.004 & & \\
\hline \multirow[t]{2}{*}{274} & $\operatorname{dex} D D$ & 7 & 19.23 & 0.14 & -1.20 & 0.236 & 0.501 & 0.007 & 0.31 & 0.759 \\
\hline & $\sin S D / S S$ & 39 & 19.52 & 0.10 & & & 0.499 & 0.003 & & \\
\hline \multirow[t]{2}{*}{277} & $\operatorname{dex} D D$ & 7 & 19.36 & 0.25 & 0.22 & 0.825 & 0.501 & 0.006 & 0.83 & 0.417 \\
\hline & $\sin S D / S S$ & 19 & 19.28 & 0.19 & & & 0.495 & 0.004 & & \\
\hline \multirow[t]{2}{*}{375} & $\operatorname{dex} D D$ & 20 & 19.58 & 0.19 & 2.27 & $0.033^{*}$ & 0.504 & 0.004 & -2.40 & $0.025^{*}$ \\
\hline & $\sin S D / S S$ & 5 & 18.54 & 0.49 & & & 0.527 & 0.008 & & \\
\hline \multirow[t]{2}{*}{376} & $\operatorname{dex} D D$ & 12 & 19.51 & 0.28 & 0.43 & 0.671 & 0.508 & 0.005 & 0.68 & 0.503 \\
\hline & $\sin S D / S S$ & 9 & 19.32 & 0.33 & & & 0.501 & 0.008 & & \\
\hline \multirow[t]{2}{*}{440} & $\operatorname{dex} D D$ & 6 & 18.98 & 0.28 & 0.10 & 0.923 & 0.493 & 0.005 & -1.06 & 0.303 \\
\hline & $\sin S D / S S$ & 17 & 18.95 & 0.20 & & & 0.502 & 0.004 & & \\
\hline \multirow[t]{2}{*}{453} & $\operatorname{dex} D D$ & 22 & 18.77 & 0.18 & 3.98 & $0.000^{* * *}$ & 0.499 & 0.006 & -2.23 & $0.033^{*}$ \\
\hline & $\sin S D / S S$ & 14 & 17.76 & 0.14 & & & 0.518 & 0.005 & & \\
\hline \multirow[t]{2}{*}{454} & $\operatorname{dex} D D$ & 9 & 19.18 & 0.17 & 1.62 & 0.119 & 0.496 & 0.008 & -0.88 & 0.390 \\
\hline & $\sin S D / S S$ & 15 & 18.65 & 0.23 & & & 0.503 & 0.005 & & \\
\hline \multirow[t]{2}{*}{455} & $\operatorname{dex} D D$ & 13 & 18.82 & 0.21 & -0.11 & 0.915 & 0.511 & 0.007 & 0.69 & 0.503 \\
\hline & $\sin S D / S S$ & 5 & 18.86 & 0.37 & & & 0.502 & 0.008 & & \\
\hline \multirow[t]{2}{*}{457} & $\operatorname{dex} D D$ & 7 & 19.30 & 0.15 & 1.45 & 0.171 & 0.500 & 0.006 & -3.43 & $0.004^{* *}$ \\
\hline & $\sin S D / S S$ & 8 & 18.84 & 0.27 & & & 0.527 & 0.005 & & \\
\hline \multirow[t]{2}{*}{458} & $\operatorname{dex} D D$ & 13 & 18.64 & 0.24 & 1.38 & 0.179 & 0.504 & 0.005 & -0.73 & 0.474 \\
\hline & $\sin S D / S S$ & 14 & 18.18 & 0.23 & & & 0.509 & 0.006 & & \\
\hline
\end{tabular}

*Significant difference by two-tailed $t$-test, $P<0.05 ;{ }^{* *} P<0.01$; ${ }^{* * *} P<0.001$. Comparisons in the expected direction (sinistrals shorter but stouter) are indicated by a bold $t$-value.

$S D$ snails are significantly longer than sinistral $S D / S S$ snails $(P<0.037)$ and very significantly slimmer $(P<0.007)$. Over the three genetically dextral $(D D)$ populations, the average length of dextral snails is $0.093 \mathrm{~mm}( \pm 0.119)$ greater than sinistral snails; similarly, dextral $S D$ snails in four populations are $0.420 \mathrm{~mm}$ $( \pm 0.169)$ longer than sinistral SD/SS snails. In contrast, the stoutness of sinistral $D D$ snails was less than that of dextral $D D$ snails $(0.991 \pm 0.016)$; however, sinistral snails of genotype $S D / S S$ snails are $1.033 \pm 0.013$ times stouter than dextral snails of a similar genotype.

As the analyses above were limited in the numbers that we could use, compared with the total number for which genotypes were determined, another paired analysis was carried out, controlling for the pooling of population samples by always including the same number of each type from a population. The result was essentially the same as those found as in Tables 3 and 4: dextral $D D$ snails were longer than dextral $S D$ snails by $\sim 0.28 \mathrm{~mm}(P<0.03)$, indicating an effect of the snails' own genotypes. Sinistral $S D / S S$ snails had a greater $w / 1$ ratio than dextral SD snails (1.018 time stouter; $P<0.001)$, indicating a maternal effect on shape (Table 5).

A further analysis compared snails that differ in both phenotype and genotype (Table 6). The length of dextral $D D$ snails was greater than sinistral SD/SS snails in 10 of 
13 comparisons (3 individually significant), the same snails also being less stout in 9 of 13 comparisons (3 significant). Using the Z-method to combine across the table, we found that dextrals were $0.375 \mathrm{~mm}( \pm 0.073)$ longer $(P<0.0001)$ and sinistrals were $1.018( \pm 0.002)$ times stouter $(P<0.003)$.

In summary, we found that dextral $S D$ snails are consistently less stout than sinistral $S D / S S$ snails (Tables 4 and 5), implying a maternal effect on shell shape, with perhaps a weaker maternal effect on shell length (Table 4). However, there is also a direct genotypic effect on shell length, because dextral $D D$ snails are taller than dextral SD snails, but no evidence of such an effect on stoutness (Tables 3 and 5). These observations imply that the sinistral allele, or an allele at a linked locus, is dominant in its effect on shell length. Inferences from Table 3 indicate, albeit less strongly, that direct genotypic effects also contribute to the length and stoutness of sinistral $D D$ compared to sinistral SD/SS snails.

\section{Precautionary analysis}

Two procedures were undertaken to guard against the possibility of measurer bias. First, a left-handed person (Sara Goodacre) measured a subset of snails (total $n=86$ ). Consistent with the results of NC, sinistrals were consistently shorter and stouter than dextrals. Second, two sample populations $(453, n=70$ and $457, n=35$ ) were measured from digital photographs, having first 'mirror-imaged' the sinistral shells so that they appeared dextral. The same trend and significant results were found, irrespective of whether the digital photograph or calipers were used (Supplementary Tables S1 and S2). The exception was a comparison of $w / 1$ in population 453, where using the digital images we found that sinistrals were significantly more stout, although the trend was the same using the caliper measures. The correlation between individual measures of length, calipers versus digital, was strong and not dependent on chirality ( $r^{2}$ length dextrals $=89.4 \% ; r^{2}$ length sinistrals $=95.8 \%$ ). The same was found for $\mathrm{w} / 1$, though the correlation was less strong $\left(r^{2}\right.$ length dextrals = $56.0 \% ; r^{2}$ length sinistrals $\left.=54.2 \%\right)$.

The digital images also enabled a comparison of the traditional measure of width (perp-W) against our own (Supplementary Table S2). The correlation between the perp-W/length ratio and the width/length ratio was strong $\left(r^{2}=90.0\right.$ and $85.5 \%$ for dextrals and sinistrals). Thus, as the overall coefficients of variation in sinistral and dextral shells were also similar, averaging about 3-4\% for both length and width/length ratio, we are confident that the results reported are not due to errors by the recorder, or to consistent biases in the measurements.

\section{Discussion}

We aimed to understand the relationship between the coil of a snail shell, and the effect of both the maternal genotype and individual's own genotype on adult shell shape. Overall, the results contrast with those of Johnson's (1987) study of Partula. He found that an individual's genotype ( $D D$ compared to $S D / S S$ ) contributes to the shell shape of sinistral individuals, but saw no evidence for a maternal effect on shell shape. We too report a direct effect of genotype on the length of shells, but through differences between $D D$ and $S D$ genotypes among dextral snails. Moreover, we also found evidence of a maternal effect on shell shape; genetically sinistral snails $(S D, S S)$ that are also sinistral in phenotype tend to be consistently stouter (that is, with a larger $\mathrm{w} / 1$ ratio) than dextral snails of genotype $S D$. However, snails with dextral genotypes $(D D)$ seem to have no such differences between sinistral and dextral phenotypes.

It is of course possible that genotypic or phenotypic effects on shell length and stoutness are not caused by the chirality locus itself, but by a locus or loci in linkage disequilibrium with it. For example, a maternal effect on shell shape might be caused by direct differences in the maternal environment during embryonic growth, but the differences might indirectly be consequences of a proportionately greater inheritance of genes from a sinistral background, rather than due to the chirality locus itself (by definition, a sinistral snail must inherit a greater proportion of its maternal genome from a sinistral background compared with a dextral, even if both have the same chirality genotype). To understand the data more clearly, we plotted the percent sinistrals in a population against $\mathrm{w} / \mathrm{l}$ ratio. Because of a large-scale NW to SE cline in shell shape, a high frequency of sinistrals in a population was associated with longer and slimmer shells, a trend contrary to that found within populations (Supplementary Figure S1; no such relationship was found by Johnson (1987), see his Figure 2). Illustrating how little of the overall (island-wide) variation in length and shape is actually associated with the chirality locus, this may explain some of the differences between our study and that of Johnson.

The majority of $P$. suturalis populations are monomorphic for coil except for very rare variants. Dimorphic populations only exist in narrow zones of transition. As each population must inevitably tend toward a different size and shape, depending on the effects of local selection, drift and gene flow, it is likely that clines in chirality will coincide with clines at other loci (Johnson et al., 1987; Goodacre and Wade, 2001), including those contributing to length and stoutness. By this reasoning, the discrepancies between our results and those of Johnson, the genotypic effect on length that we found in dextrals, and the effect on shape that Johnson found in sinistrals, could be caused by the chirality locus itself, or else by genes in linkage disequilibrium with it. The results are likely discrepant because each study was conducted in a different region, with differently shaped and sized shells and different proportions of each chirality allele. In our study, predominantly sinistral populations tended to be longer and less stout, whereas predominantly dextral populations were shorter and stouter, so hybrid populations must inevitably have dragged some of the 'baggage' of linked loci with them, reducing the sensitivity of our analysis compared with that of Johnson (1987).

There is another intriguing aspect of the data. Our analyses, and those of Johnson's (1987), strictly control both genotype and phenotype, but a crucial element in offspring shape and size could be a combination of the two. It could explain why some of the biggest differences (in both studies) involve comparisons between sinistral and dextral phenotypes, apparently irrespective of genotype (Table 1; Figure 1; Johnson's Figure 1), because sinistral snails are usually $S D$ or $S S$, and dextral snails 
are usually $D D$ (Figure 4). If the maternal-offspring combination is important, the greatest difference should perhaps be between sinistral $S D / S S$ and dextral $D D$ snails. This is certainly true for length (Table 6); dextral $D D$ snails are $0.38 \mathrm{~mm}$ longer than sinistral $S D / S S$ snails. An effect of loci in linkage disequilibrium solely because of gene flow is not a likely explanation, because nearby pure sinistral populations tend to be larger and slimmer than nearby pure dextral populations. The data from sample 132, the only sample with adequate numbers of all four combinations of genotypes, suggest that maternal and fetal genotypes act additively or multiplicatively together on size and shape. The proportional change produced by differing genotypes within the offspring seems to be roughly the same whether the offspring are dextral or sinistral (that is, whatever is the genotype of the mother). Correspondingly, the proportional change produced by different genotypes in the mother is roughly the same regardless of the genotypes in the offspring. The dextral DD snails are the longest and the sinistral SD/SS are the stoutest. The sample sizes are too small to assess definitively whether the combinations of genotypic effects are strictly additive or multiplicative.

\section{Chiral evolution}

This work is relevant to understanding chiral evolution in snails, because it shows that the effects of chirality genes on shell size and shape are complex, involving elements of the maternal genotype, of the individual's genotype and perhaps nonadditive interactions between the two. The genotype and phenotype of maternally inherited loci also tend to be coupled (Figure 4), probably exacerbated by assortative mating. Thus, although changes in shell shape are not necessary concomitants of chiral evolution (contrary to Gould et al., 1985), they indicate wider 'pleiotropic' effects of the haplotypes concerned. We therefore conclude that neither of the views offered by Johnson (1987) or Gould et al. (1985) is completely correct.

\section{Wider relevance}

More generally, the work should be relevant to the general understanding of the dynamics of genes that act through the mother (Kirkpatrick and Lande, 1989; Lande and Kirkpatrick, 1990; Kirkpatrick and Barton, 2006), including how selection acts on them. The Partula data set is a rare record of an association in nature between the phenotype and genotype of a maternal-effect locus. Thus, even though Medea loci (Maternal-Effect Dominant Embryonic Arrest) have been the subject of continuing and detaile $\bar{d}$ molecular genetic study (Lorenzen et al., 2008), field surveys have concentrated on their geographic occurrence, while neglecting the details of maternal-offspring transmission (Beeman and Friesen, 1999; Beeman, 2003).

The strong association that we found between maternal phenotype and individual genotype (Figure 4) is interesting because it implies that for at least some maternal effect genes, the potential disconnect between phenotype and genotype might not always be critical in trying to understand how natural selection operates with non-Mendelian inheritance. The association between the phenotype and genotype of maternal effect genes is, however, particularly relevant to loci that are implicated in causing adult infertility, such as mago nashi (Boswell et al., 1991), and/or hybrid sterility, such as the 'Medea' elements (Beeman and Friesen, 1999). For the same reason that the snail chirality locus is not an isolating agent in isolation-the disconnection between genotype and phenotype allows indirect gene flow between coiling morphs that are absolutely unable to mate (Johnson et al., 1990; Davison et al., 2005)-maternal effect genes, including selfish genetic elements, are likely to have only a limited contribution to post-zygotic isolation unless they also contribute to mate choice (Hurst and Schilthuizen, 1998).

\section{Addendum}

AD recently came across an interesting early comment on the issues discussed in this paper. One of us (BCC) was bequeathed a copy of Crampton (1916) that was owned and annotated by Captain Cyril Diver. Alongside Crampton's text (referring to Partula otaheitana otaheitana; p. 124) that 'the most striking results of comparing the two classes on the basis of dimensional statistics (table 58 ) is the fact that the sinistral shells are certainly shorter in total length, and certainly stouter in shell proportions; the differences are respectively 5 and 6 times their probable errors' there is a penciled comment by Diver 'as in Limnaea apparently ... when they are closely related, is this a function of the sinistral factor or a linkage?'. Recent work seems to reiterate the same findings (Asami et al., 2007), though we still do not know the complete answer to Diver's question.

\section{Acknowledgements}

We thank Ann Clarke and Elizabeth Murray for their help in the field, to Lorna Stewart for taking the initial shell measurements, to Sara Goodacre for being the lefthander, to Michael Johnson and several anonymous referees for comments on the paper and to Marcus Eichhorn for advice on statistics. Work in the field was supported by the Royal Society, The Carnegie Trust, the Percy Sladen Trust and the National Science Foundation. The Science Research Council (B/SR/4144), the National Science Foundation (GB-4188) and the University of Nottingham supported work in the laboratory.

\section{References}

Arthur W (1999). Variable segment number in centipedes: population genetics meets evolutionary developmental biology. Evol Dev 1: 62-69.

Asami T, Cowie RH, Ohbayashi K (1998). Evolution of mirror images by sexually asymmetric mating behavior in hermaphroditic snails. Am Nat 152: 225-236.

Asami T, Utsuno H, Gittenberger E (2007). Developmental Constraint and Stabilizing Selection against Left-Right Reversal in Snails. World Congress of Malacology: Antwerp.

Beeman RW (2003). Distribution of the Medea factor M-4 in populations of Tribolium castaneum (Herbst) in the United States. J Stored Prod Res 39: 45-51.

Beeman RW, Friesen KS (1999). Properties and natural occurrence of maternal-effect selfish genes ('Medea' factors) in the red flour beetle Tribolium castaneum. Heredity 82: 529-534.

Boswell RE, Prout ME, Steichen JC (1991). Mutations in a newly identified Drosophila melanogaster gene, mago nashi, disrupt germ cell formation and result in the formation of mirror 
image symmetrical double abdomen embryos. Development 113: $373-384$.

Boycott AE, Diver C (1923). On the inheritance of sinistrality in Limnaea peregra. Proc R Soc Biol Sci Ser B 95: 207-213.

Boycott AE, Diver C, Garstang SL, Turner FM (1930). The inheritance of sinistrality in Limnaea peregra (Mollusca, Pulmonata). Philos Trans $R$ Soc Lond B Biol Sci 219: 51-130.

Clarke B, Murray J (1969). Ecological genetics and speciation in land snails of the genus Partula. Biol J Linn Soc 1: 31-42.

Crampton HE (1916). Studies on the variation, distribution, and evolution of the genus Partula. The species inhabiting Tahiti. Carnegie Mus Nat Hist Spec Publ 228: 1-311.

Crampton HE (1924). The coincident production of dextral and sinistral young in the land-gastropod Partula. Science 59: 558-559.

Crampton HE (1932). Studies on the variation, distribution, and evolution of the genus Partula. The species inhabiting Moorea. Carnegie Mus Nat Hist Spec Publ 410: 1-335.

Davison A, Chiba S, Barton NH, Clarke BC (2005). Speciation and gene flow between snails of opposite chirality. PLoS Biol 3: e282.

Freeman G, Lundelius JW (1982). The developmental genetics of dextrality and sinistrality in the gastropod Lymnaea peregra. Roux Arch Dev Biol 191: 69-83.

Gilbert SF (1998). Bearing crosses: a historiography of genetics and embryology. Am J Med Genet 76: 168-182.

Gilbert SF (2006). Developmental Biology. Sinauer: Sunderland, MA.

Goodacre SL, Wade CM (2001). Patterns of genetic variation in Pacific island land snails: the distribution of cytochrome $b$ lineages among Society Island Partula. Biol J Linn Soc 73 131-138.

Gould SJ, Young ND, Kasson B (1985). The consequences of being different-sinistral coiling in Cerion. Evolution 39: 1364-1379.

Grande C, Patel NH (2008). Nodal signalling is involved in leftright asymmetry in snails. Nature 457: 1007-1011.

Gurdon JB (2005). Sinistral snails and gentlemen scientists. Cell 123: $751-753$

Hierck BP, Witte B, Poelmann RE, Gittenberger-de Groot AC, Gittenberger E (2005). Chirality in snails is determined by highly conserved asymmetry genes. J Molluscan Stud 71: 192-195.

Hurst GDD, Schilthuizen M (1998). Selfish genetic elements and speciation. Heredity 80: 2-8.

Johnson MS (1982). Polymorphism for direction of coil in Partula suturalis-behavioral isolation and positive frequency-dependent selection. Heredity 49: 145-151.

Johnson MS (1987). Adaptation and rules of form-chirality and shape in Partula suturalis. Evolution 41: 672-675.
Johnson MS, Clarke B, Murray J (1990). The coil polymorphism in Partula suturalis does not favor sympatric speciation. Evolution 44: 459-464.

Johnson MS, Murray J, Clarke B (1987). Independence of genetic subdivision and variation for coil in Partula suturalis. Heredity 58: 307-313.

Johnson MS, Murray J, Clarke B (1993). The ecological genetics and adaptive radiation of Partula on Moorea. Oxf Surv Evol Biol 9: 167-238.

Kirkpatrick M, Barton N (2006). Chromosome inversions, local adaptation and speciation. Genetics 173: 419-434.

Kirkpatrick M, Lande R (1989). The evolution of maternal characters. Evolution 43: 485-503.

Lande R, Kirkpatrick M (1990). Selection response in traits with maternal inheritance. Genet Res 55: 189-197.

Levin M, Palmer AR (2007). Left-right patterning from the inside out: widespread evidence for intracellular control. Bioessays 29: 271-287.

Lipton CS, Murray J (1979). Courtship of lands snails of the genus Partula. Malacologia 19: 129-146.

Lorenzen MD, Gnirke A, Margolis J, Garnes J, Campbell M, Stuart JJ et al. (2008). The maternal-effect, selfish genetic element Medea is associated with a composite Tc1 transposon. Proc Natl Acad Sci USA 105: 10085-10089.

Morisato D, Anderson KV (1995). Signaling pathways that establish the dorsal-ventral pattern of the Drosophila embryo. Annu Rev Genet 29: 371-399.

Murray J, Clarke B (1968). The inheritance of shell size in Partula. Heredity 23: 189-198.

Murray J, Clarke B (1976a). Supergenes in polymorphic land snails 1. Partula taeniata. Heredity 37: 253-269.

Murray J, Clarke B (1976b). Supergenes in polymorphic land snails 2. Partula suturalis. Heredity 37: 271-282.

Orr HA (1991). Is single-gene speciation possible? Evolution 45: 764-769.

Shibazaki Y, Shimizu M, Kuroda R (2004). Body handedness is directed by genetically determined cytoskeletal dynamics in the early embryo. Curr Biol 14: 1462-1467.

Stone J, Björklund M (2002). Delayed prezygotic isolating mechanisms: evolution with a twist. Proc $R$ Soc Biol Sci Ser B 269: 861-865.

Sturtevant AH (1923). Inheritance of direction of coiling in Limnaea. Science 58: 269-270.

van Batenburg FHD, Gittenberger E (1996). Ease of fixation of a change in coiling: computer experiments on chirality in snails. Heredity 76: 278-286.

Whitlock MC (2005). Combining probability from independent tests: the weighted Z-method is superior to Fisher's approach. J Evol Biol 18: 1368-1373.

Wood WB (2005). The left-right polarity puzzle: determining embryonic handedness. PLOS Biol 3: 1348-1351.

Supplementary Information accompanies the paper on Heredity website (http://www.nature.com/hdy) 